\title{
Modified erythrocytes in indirect haemagglutination with Neisseria gonorrhoeae antigen
}

\author{
J. A. MAELAND, F. WESENBERG*, AND O. TÖNDER \\ Broegelmann Research Laboratory for Microbiology and Department of Microbiology, Gade Institute, University \\ of Bergen, School of Medicine, Bergen, Norway
}

Antigen prepared from gonococci by extraction with alkali has the ability to sensitize erythrocytes for agglutination or indirect haemolysis by corresponding antisera (Chanarin, 1954; Mæland, 1966; Thomas and Mennie, 1950). These indirect techniques have been used for the study of endotoxin preparations from gonococci. Endotoxins, however, require treatment with alkali before sensitization, except when the extraction procedure includes exposure of the antigen to alkali (Mæland, 1968, 1969b). Untreated erythrocytes were always used for sensitization with the alkali-treated antigens.

Attempts have been made to use the indirect haemagglutination technique for detection of antibodies to gonococci, omitting alkali-treatment of the antigens. This report presents results which show that antigen present in saline extracts from gonococci has the ability to sensitize tanned or formalinized erythrocytes. Treatment of the antigen with alkali could then be omitted.

\section{Material and methods}

$\mathrm{N}$. gonorrhoeae strain

Strain 8551, described in previous reports (Mæland, 1966), was used. The bacteria were cultured on placental broth agar, harvested in 0.85 per cent. sodium chloride (saline), and collected by centrifugation at $10,000 \times \mathrm{G}$. for $20 \mathrm{~min}$. (at approximately $10^{\circ} \mathrm{C}$.). The supernatant was saved and the bacteria were stored frozen until used.

\section{Preparation of extracts from gonococci}

Saline extracts were prepared by suspending gonococci in saline ( $1 \mathrm{~g}$. wet bacteria in $4 \mathrm{ml}$.). The suspension was kept at $4^{\circ} \mathrm{C}$. for 4 days. The bacteria were then removed by centrifugation at $30,000 \times \mathrm{G}$. for $60 \mathrm{~min}$. and the supernatant (the saline extract) was stored frozen. Similarly prepared extract of placental broth agar served as control.

Received for publication September 22, 1972

*Supported by student grant E. 01.01-2 from the Norwegian Research Council for Science and the Humanities
Aqueous ether endotoxin was prepared as previously described (Mæland, 1968, 1969a). After extraction of the bacteria with a mixture of saline and diethyl ether, the endotoxin was purified by treatment with DNase and repeated washings with distilled water. The lyophilized preparation was dissolved in $0.01 \mathrm{~N} \mathrm{NaOH}$ neutralized with $\mathrm{HCl}$ and dialysed against phosphate buffered saline pH $7 \cdot 2$ (final concentration $1 \mathrm{mg}$. $/ \mathrm{ml}$.).

\section{Preparation of antisera}

Rabbit antisera to whole gonococci and to gonococci heated at $100^{\circ} \mathrm{C}$. for $60 \mathrm{~min}$. were prepared according to the immunization schedule described earlier (Mæland, 1966). Antiserum to erythrocytes sensitized with alkalitreated aqueous ether endotoxin was prepared as previously (Mæland, 1969b).

\section{Erythrocytes}

Human $\mathrm{O} R \mathrm{Rh}$-negative erythrocytes were obtained from whole blood collected in ACD-solution and sheep erythrocytes from blood collected in Alsever's solution. The erythrocytes were washed three times with 6 to 10 volumes of phosphate-buffered saline and packed by centrifugation at $1,000 \times \mathrm{G}$. for $5 \mathrm{~min}$.

Formalinized erythrocytes were prepared as described by Daniel, Weyand, and Stavitsky (1963).

Tanned erythrocytes were prepared by making a 1.5 per cent. suspension of erythrocytes in tannic acid diluted 1 in 80,000 in phosphate-buffered saline (w/v). The mixture was kept at $20^{\circ} \mathrm{C}$. for $20 \mathrm{~min}$. The erythrocytes were washed twice and finally prepared as a 1.5 per cent. suspension in phosphate-buffered saline.

\section{Sensitization of erythrocytes}

Equal volumes of saline extract and 1.5 per cent. suspension of untreated, tanned, or formalinized erythrocytes were mixed. The mixtures were left at various temperatures for various lengths of time, as shown in the Results section. The sensitized erythrocytes were washed three times and finally prepared as a $0 \cdot 75$ per cent. suspension in phosphate-buffered saline.

Erythrocytes were sensitized with determinant $a$ or $b$ of aqueous ether endotoxin as described previously (Mæland, 1969b). Briefly, the preparation used for sensitization with determinant $a$ was endotoxin treated with $0.04 \mathrm{~N} \mathrm{NaOH}$, neutralized and then digested with 
pronase. The preparation used for sensitization with determinant $b$ was endotoxin treated with $0.008 \mathrm{~N} \mathrm{NaOH}$, neutralized and oxidized with sodium meta-periodate.

\section{Haemagglutination test}

All sera were absorbed with unsensitized erythrocytes which were untreated, tanned, or formalinized depending on the test. Equal volumes of packed erythrocytes and serum diluted 1 in 2 were mixed, kept at room temperature for $30 \mathrm{~min}$., and centrifuged. 2-fold dilutions of absorbed serum were prepared in $0.1 \mathrm{ml}$. volumes of phosphatebuffered saline, $0.1 \mathrm{ml}$. of sensitized erythrocytes being added to each tube. The racks were left at $4^{\circ} \mathrm{C}$. for $4 \mathrm{hrs}$. The agglutination was read by recording the patterns formed by the sedimented erythrocytes on the bottom of the tubes (Daniel and others, 1963). The titre was given as the reciprocal of the highest initial serum dilution at which agglutination was recorded.

Tests for inhibition of haemagglutination were performed as described previously (Mæland, 1968) using 8 agglutinating units of the antiserum.

\section{Absorption of antisera}

Absorption with whole gonococci was carried out by mixing antiserum diluted 1 in $16(1.6 \mathrm{ml}$.) and $0.2 \mathrm{~g}$. of wet bacteria, either untreated or heated at $100^{\circ} \mathrm{C}$. for $60 \mathrm{~min}$. Absorption with saline extract was performed by adding $1.5 \mathrm{ml}$. of the extract to $0.1 \mathrm{ml}$. of undiluted antiserum and with aqueous ether endotoxin by adding $3 \mathrm{mg}$. of the preparation dissolved in $1.5 \mathrm{ml}$. volume to $0.1 \mathrm{ml}$. of the antiserum. The mixtures were kept at $4^{\circ} \mathrm{C}$. for $20 \mathrm{hrs}$ and cleared by centrifugation at $10,000 \times$ G. for $20 \mathrm{~min}$. The supernatants were saved (absorbed sera.)

\section{Other methods}

Aqueous ether endotoxin was digested with pronase or oxidized with periodate as described previously (Mæland, 1968).

\section{Results}

\section{Sensitization of erythrocytes with saline extract}

Untreated human or sheep erythrocytes were exposed to undiluted or diluted samples of the saline extract for various lengths of time and at different temperatures, 4,20 , or $37^{\circ} \mathrm{C}$. These erythrocytes were not agglutinated by the antisera to gonococci. Apparently, the saline extract failed to sensitize untreated erythrocytes.

Unlike untreated erythrocytes, tanned erythrocytes were agglutinated by the extract. The possibility of eliminating or reducing this agglutination was examined by re-suspension of the erythrocytes in various dilutions of serum from different species (man, horse, pig, sheep, rabbit, guinea-pig, rat, and mouse) and in various concentrations of bovine albumin. These methods, however, proved ineffective. When incubated with sub-agglutinating doses of the saline extract, these erythrocytes, like untreated samples, were not agglutinated by any of the antisera used. The agglutination of tanned erythrocytes incubated at $37^{\circ} \mathrm{C}$. with agglutinating doses of the extract was intensified by antiserum to gonococci, but not by normal rabbit serum. Apparently the antigen present in the saline extract attached to the surface of tanned erythrocytes. However, the difficulties encountered in interpretation of the results seriously hampered the use of the erythrocytes in indirect haemagglutination tests.

Formalinized, tanned erythrocytes were incubated with the extract at $4,20,37$, and $56^{\circ} \mathrm{C}$. for various lengths of time, and washed. These batches of erythrocytes were then used in haemagglutination with antiserum to whole gonococci. With erythrocytes incubated at $4^{\circ} \mathrm{C}$. no agglutination was observed. The results obtained in tests with erythrocytes sensitized at the other temperatures are shown in the Figure. Erythrocytes sensitized at $20^{\circ} \mathrm{C}$. gave low titres of the antiserum, while those treated at higher temperatures gave higher titres, indicating that the sensitizing activity of the antigen involved was temperature-dependent. At $56^{\circ} \mathrm{C}$. the sensitization was optimal after $5 \mathrm{~min}$., whereas at $37^{\circ} \mathrm{C}$. $30 \mathrm{~min}$. was required.

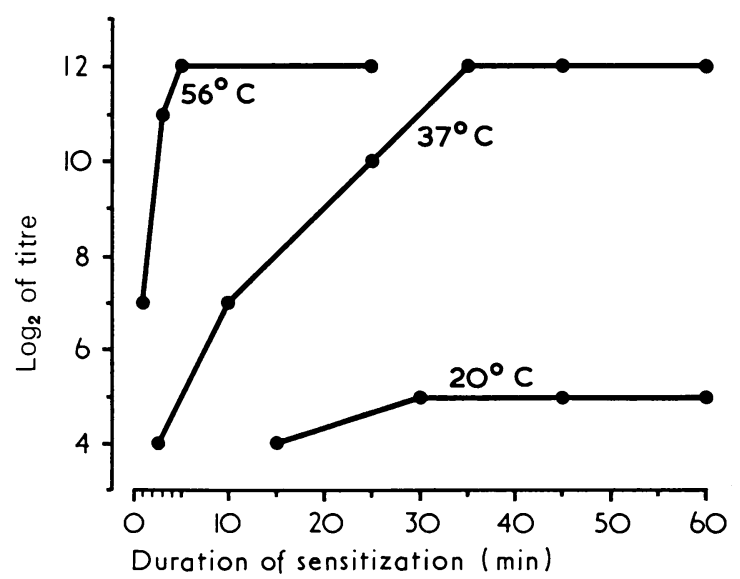

FIGURE Indirect haemagglutination test with tanned, formalinized erythrocytes sensitized with saline extract of gonococci. Effect on mode titre of a rabbit antiserum of sensitization carried out at different temperatures and for various lengths of time

Results of further experiments with formalinized erythrocytes showed that treatment with tannic acid was a prerequisite for sensitization at $37^{\circ} \mathrm{C}$. or lower temperatures. On the other hand, at $56^{\circ} \mathrm{C}$., 
the sensitization was equally strong using erythrocytes which had not been treated with tannic acid. Heating of the extract and of erythrocytes in separate tubes at $56^{\circ} \mathrm{C}$. followed by cooling before sensitization at different temperatures gave results identical to those described. These findings indicated that optimal results in the haemagglutination reaction depended on the temperature during sensitization.

In all experiments results obtained with human erythrocytes were similar to those obtained with sheep erythrocytes. In later experiments erythrocytes treated only with formaldehyde were employed. Sensitization was carried out at $56^{\circ} \mathrm{C}$. for $15 \mathrm{~min}$. by incubation with extract diluted 1 in 16 .

Activity of saline extract and of aqueous ether endotoxin in inhibition and absorption experiments

Tests for inhibition of haemagglutination were performed using untreated sheep erythrocytes sensitized with determinant $a$ or $b$ of aqueous ether endotoxin and formalinized erythrocytes sensitized with the saline extract. Both saline extract and aqueous ether endotoxin gave inhibition of haemagglutination in all three test systems (Table). The findings indicate that determinants $a$ and $b$ of the endotoxin preparation were present in the saline extract. Furthermore, the endotoxin preparation contained the determinant group (or groups) present on erythrocytes sensitized with the saline extract.

TABLE Inhibition of indirect haemagglutination. Antigen preparations from gonococci examined for inhibition in 3 test systems. Activity expressed as reciprocal of highest dilution giving complete inhibition

\begin{tabular}{|c|c|c|c|}
\hline \multirow{3}{*}{ Preparations } & \multicolumn{3}{|c|}{ Erythrocytes sensitized with } \\
\hline & \multirow{2}{*}{$\begin{array}{l}\text { Saline } \\
\text { extract }\end{array}$} & \multicolumn{2}{|c|}{ Determinant } \\
\hline & & $\mathbf{a}$ & b \\
\hline $\begin{array}{l}\text { Saline extract } \\
\text { Endotoxin }^{\mathrm{a}}\end{array}$ & 256 & 16 & 16 \\
\hline Untreated & 128 & 64 & 32 \\
\hline Treated with periodate & $<1$ & $<1$ & 32 \\
\hline Treated with pronase & $<1$ & 64 & $<1$ \\
\hline Supernatant of harvest & 64 & 16 & 8 \\
\hline Extract of culture medium & $<1$ & $<1$ & $<1$ \\
\hline
\end{tabular}

a $1 \mathrm{mg} . / \mathrm{ml}$.

Treatment of endotoxin with periodate or pronase affected the activity of determinants $a$ and $b$ as previously reported (Mæland, 1968). Unlike the effect on these determinants, the ability of endotoxin to inhibit the agglutination of erythrocytes sensitized with the saline extract was destroyed both by periodate and pronase. Nor did endotoxin treated with periodate and endotoxin digested with pronase give any inhibition when mixed together.

The supernatant recovered after centrifugation of the saline harvest of gonococci possessed inhibitory activity in all three test systems, indicating the presence of the antigen involved. Antibodies to the saline extract antigen, as well as to determinants $a$ and $b$, were removed by absorption with wet or boiled gonococci, saline extract and endotoxin. Saline extract of placental broth agar gave no inhibition and the culture medium did not absorb the antibodies to any of the antigens.

Titration of antisera and pre-immune sera showed that antibodies to the saline extract antigen were produced by animals immunized with untreated gonococci, boiled bacteria, or erythrocytes sensitized with aqueous ether endotoxin. The titres of the antisera varied from 512 to 4,096 , whereas the titres of the pre-immune sera were below 16 .

\section{Discussion}

Saline extracts of gonococci contained antigen(s) which sensitized tanned and/or formalinized erythrocytes for agglutination by antisera. Untreated erythrocytes were not sensitized. The results obtained in the haemagglutination reaction with tanned erythrocytes were difficult to reproduce because of agglutination by the saline extract. This is consistent with observations made by other workers (Danielsson, Schmale, and Lee, 1970).

Formalinized erythrocytes gave reproducible results. Furthermore, treatment with tannic acid could be omitted, provided the sensitization was carried out at $56^{\circ} \mathrm{C}$. At $37^{\circ} \mathrm{C}$. or lower temperatures only tanned erythrocytes were sensitized. The avidity of the antigen for the surface of modified erythrocytes was greatly increased by elevating the temperature, indicating that sensitization was temperature-dependent. In order to obtain reproducible results in the haemagglutination test, it was thus necessary to pay great attention to the sensitization procedure.

Sensitization of erythrocytes with bacterial or other antigens has usually been performed by incubation at temperatures not higher than $37^{\circ} \mathrm{C}$. The present study with formalinized erythrocytes has shown that antigens which fail to sensitize erythrocytes at $37^{\circ} \mathrm{C}$. may do so at $56^{\circ} \mathrm{C}$.

Results of absorption and inhibition experiments provided evidence that the sensitizing antigen originated from the gonococci and not from the culture medium. This antigen and the endotoxin were present both in the saline extract and in a saline harvest of gonococci. This finding was unexpected, since it is generally recognized that vigorous 
extraction methods are required for the preparation of endotoxins. However, some earlier results have suggested that a portion of the endotoxin from Gramnegative bacteria can easily be released (Crutchley, Marsh, and Cameron, 1968). The antigens present in saline extracts and saline harvests of gonococci probably represent only part of components which require more vigorous methods for their complete extraction.

A purified endotoxin preparation contained the antigenic determinant carried by erythrocytes sensitized with the saline extract. Accordingly, the sensitizing antigen present in the extract might be identical to the endotoxin.

It was earlier shown that determinant $a$ belongs to the carbohydrate component and determinant $b$ to the protein component of aqueous ether endotoxin (Mæland, 1968, 1969a). While oxidation with periodate destroyed determinant $a$ but not determinant $b$, digestion with pronase had the opposite effect (Mæland, 1968). This was verified in the present study. Endotoxin, however, whether treated with periodate or pronase, lost its ability to neutralize antibody to the saline extract antigen. Accordingly, it seems unlikely that the determinant group carried by erythrocytes sensitized with the saline extract was identical to either $a$ or $b$. Absorption of antisera to gonococci should be performed using erythrocytes sensitized by the various antigen preparations, but such experiments require large samples of antigen.

More information is needed in order to establish the relationship between the sensitizing antigen in the saline extract and the endotoxin complex. Also the chemical nature of the saline extract antigen, its presence in other strains of gonococci, and its possible antigenicity in connection with human infections should be investigated. The destruction of the activity of the antigen by digestion with pronase indicates that the antigen may be of protein nature, a possibility which is not excluded by the simultaneous destruction by oxidation with periodate.

\section{Summary}

The sensitizing ability of antigen in saline extracts of gonococci was investigated, using an indirect haemagglutination technique with antiserum to gonococci and untreated, tanned, or formalinized erythrocytes. Untreated erythrocytes could not be sensitized. Tanned erythrocytes were sensitized but gave inconsistent results in indirect haemagglutination. Formalinized erythrocytes could be sensitized at $37^{\circ} \mathrm{C}$. after treatment with tannic acid and at $56^{\circ} \mathrm{C}$. without pretreatment with tannic acid. The saline extract antigen was present in endotoxin prepared from whole cells by extraction with aqueous ether. The results further indicate that this antigen is not identical to determinant $a$ or $b$ of the endotoxin complex.

\section{References}

Chanarin, I. (1954) f. Hyg. (Lond.), 52, 425

Crutchley, M. J., Marsh, D. G., and Cameron, J. (1968) f. gen. Microbiol., 50, 413

Daniel, T. M., Weyand, J. G. M., and Stavitsky, A. B (1963) f. Immunol., 90, 741

Danielsson, D., Schmale, J. D., and Lee, L. (1970) Acta path. microbiol. scand., 78B, 267

MÆLAND, J. A. (1966) Ibid., 67, 102

- (1968) Ibid., 73, 413

- (1969a) Ibid., 76, 475

- (1969b) Ibid., 77, 495

Thomas, J. C., and Mennie, A. T. (1950) Lancet, 2, 745

Erythrocytes modifiés dans l'hémaglutination indirecte avec l'antigène Neisseria gonorrhoeae

SOMMAIRE

Le pouvoir sensibilisant de l'antigène dans des extraits de gonocoque en sérum physiologique fut étudié en utilisant une technique indirecte d'hémaglutination avec un anti-sérum contre les gonocoques et des hématies non traitées, tannées ou formolées. Les hématies non traitées ne purent être sensibilisées. Les hématies tannées furent sensibilisées mais donnèrent des résultats incertains en hémaglutination indirecte. Les hématies formolées peuvent être sensibilisées à $37^{\circ} \mathrm{C}$. après traitement à l'acide tannique et à $56^{\circ} \mathrm{C}$. sans traitement préliminaire par l'acide tannique. L'antigène extrait par le sérum physiologique se montra présent dans l'endotoxine préparée à partir de cellules entières obtenues par extraction dans un mélange éther-eau. Les résultats indiquent de plus que cet antigène n'est pas identique au déterminant $a$ ou $b$ du complexe endotoxinique. 